Dept. of Food Hygiene,

Animal Health Research Institute, Dokki, Giza

\title{
SELENIUM LEVELS IN BLOOD SERUM, LIVER, KIDNEY AND MUSCLES OF ANIMALS SLAUGHTERED IN ISMAILIA SLAUGHTERHOUSE
}

(With 3 Tables)

By

K.M. EL-KHAWAS; MONA A. ABD EL-WAHAB and M.K. ABO-ELMAGD

(Received at 11/3/2008)

مستوى السيلينيوم فى مصل الام، الكبد، الكلى والعضلات فى الحيوانات المذبوحة فى مجزر الإسماعيلية الإلئل

خالد محمد سبي الخواص ، منس محد عبل الوهاب ، محمد كمال أبو المجد

قامت هذه الدراسة باستقصاء مستوى عنصر السيلينيوم فى مصل ونل وأنسجة (الكبد، الكلية

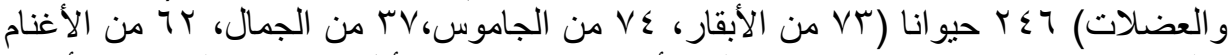

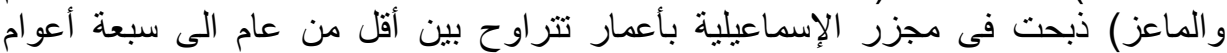

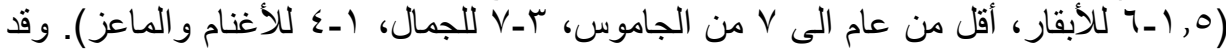

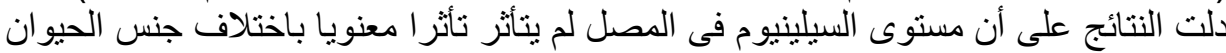

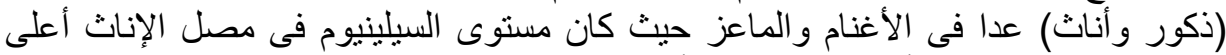

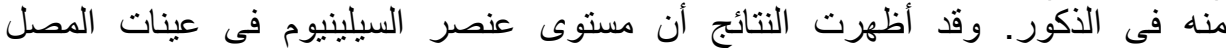

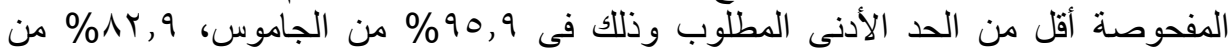

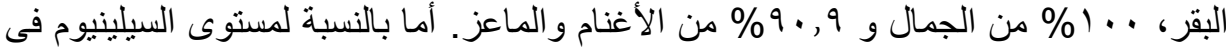

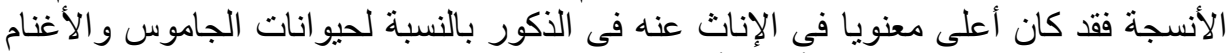

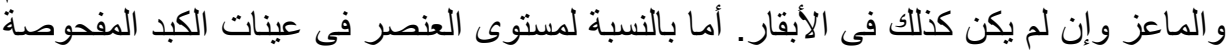

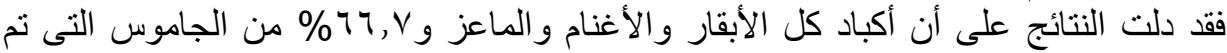

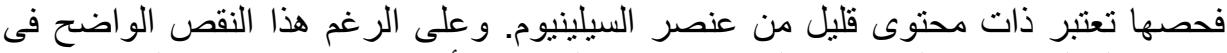

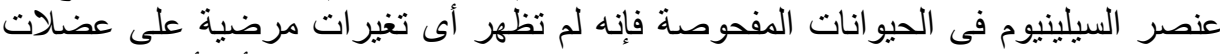

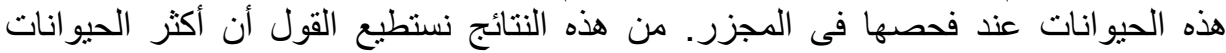

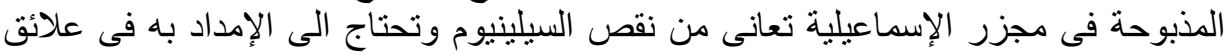
التغذية.

\section{SUMMARY}

Selenium was investigated in serum and tissues (liver, kidney and muscles) of 246 animals ( 73 cows, 74 buffaloes, 37 camels and 62 sheep $\&$ goats) ranging from less than 1 year to 7 years $(1.5-6$ for cows, $<1-7$ 
for buffaloes, 3-7 for camels and 1-4 for sheep \& goats), slaughtered in Ismailia slaughterhouse. Results revealed that selenium levels in the blood serum doesn't significantly differ $(\mathrm{P}>0.05)$ between sexes except for sheep and goats, where females had significantly higher levels than males $(\mathrm{P}<0.05)$. Serum level of selenium was considered low in $95.9 \%$ of buffaloes, $82.9 \%$ of cows, $100 \%$ of camels and $90.9 \%$ of sheep and Goats. Level of selenium in tissues of females were significantly $(\mathrm{P}<0.05)$ higher than male in buffalo, sheep and goats, but not in cow ( $P>0.05)$. Concerning the level of selenium in the liver, all cows, sheep and goats and $66.7 \%$ of buffaloes were concerned as low level. No distinct symptoms of nutritional myopathy were observed in the slaughtered animals. Most of the animals slaughtered in Ismailia slaughterhouse showed low levels of selenium and need to be supplemented with selenium in their ration.

Key words: Selenium, blood serum, liver, kidney, muscles

\section{INTRODUCTION}

Grain and cereal products are the main source of dietary selenium intake, so top soils low in selenium will affect the selenium level. In this case a regular consumption of selenium rich foods from secondary selenium sources such as sheep meat and beef is the solution for significant increase in selenium level (Kay and Knight , 1979). High levels of selenium are found in meats such as kidney (Barclay, et al., 1995).

The actual concentration of selenium is directly proportional to dietary intake. Selenium is found in two forms, organic and inorganic. The main dietary form is selenomethionine which is organic form (Smith et al., 2004). Organic Se sources (selenized yeast and Se-enriched probiotics) are more effective than the inorganic Se source (sodium selenite) in increasing tissue and blood Se concentrations (Qin et al., 2007).

As with other trace minerals, adequate level of selenium must be maintained for healthy animal. A selenium level between $0.08-0.30 \mathrm{ppm}$ in serum and $0.25-0.50 \mathrm{ppm}$ in liver of cattle is considered to be adequate. Otherwise, selenium level lower than $0.17 \mathrm{ppm}$ in liver may be considered deficient. Likewise, a toxic selenium level is above $1.25 \mathrm{ppm}$ in liver and $3.5 \mathrm{ppm}$ in serum of cattle (Puls, 1994). 
Selenium deficiency is much more common than toxicity. Symptoms of selenium deficiency include diarrhea, muscle stiffness, and sudden death due to cardiac failure and white muscle disease. Selenium deficiency is also responsible for the lowering of animal resistance for microbial infections, by affection on neutrophil function and proliferation of $\mathrm{T}$ and B lymphocytes (Swecker, 1990). Nutritional myodegeneration in lambs is associated with abnormalities in serum thyroid concentrations which can result from selenium deficiency (Kozat, 2007).

Selenium is a component of the cytosol enzyme known as glutathione peroxidase. This enzyme has a key role in intracellular oxidation-reduction reactions. Along with vitamin E, selenium prevents oxidative damage to cells (Schering, 1988). Various selenium chemical forms have been shown to differ widely in their anticancer properties (Smith et al., 2004). Selenium status has been linked to the incidence of cancer and other diseases (Alexander, 2007).

Selenium has a cumulative effect as its concentration in serum and tissues increased linearly as dietary selenium level increased and responded cubically over time especially in liver, hoof and kidney. Although the maximum tolerable level of inorganic selenium for sheep was thought to be $2 \mathrm{mg} / \mathrm{kg}$ of ration, Davis et al. (2006) found that ewes were able to tolerate up to $20 \mathrm{mg}$ of dietary selenium $/ \mathrm{kg}$ as sodium selenite for 72 weeks without observation of any clinical signs of selenium toxicosis. Excess consumption of selenium (Se) accumulator plants can result in selenium intoxication (Tiwary et al., 2006).

The supplementation with Se, for the prevention of nutritional myodystrophy degeneration in lambs, should be conducted in a fashion which does not generate high levels of Se in the ewes around the mating period. This is because of the strong interaction between synchronization and Se supplementation, causing a toxic effect on the reproductive performance of ewes. This negative effect, presumably related to high embrionary mortality caused by Se toxicity, which should be taken in account for oestrus synchronizing in Se-deficient areas (Sánchez, et al., 2008). Excess selenium can produce selenosis in humans affecting liver, skin, nails and hair (Alexander, 2007).

The aim of this study was to estimate the levels of selenium in serum and tissues of animals slaughtered in Ismailia governorate and suggesting the required subsequent action. 


\section{MATERIALS and METHODS}

A total number of 246 animal of both sexes (male and female) ranging from less than 1 year 7 years, slaughtered in Ismailia slaughterhouse were used to determine the selenium level in serum and tissues as illustrated in Table (1). Blood serum, liver, kidney and muscles were collected from cattle, buffaloes, camels, sheep and goats. The samples were collected at the time of slaughtering, then transported immediately on ice to the laboratory and kept in deep freezer at $-18{ }^{\circ} \mathrm{C}$ until preparation for digestion. The slaughtered animals were inspected in the slaughterhouse for myodegeneratoins in heart and different muscles.

Table 1: Number, sex and age of investigated animals

\begin{tabular}{|l|c|c|c|c|}
\hline Species & No. & Male & Female & Age range (years) \\
\hline Buffalo & 74 & 44 & 30 & $<1-7$ \\
\hline Cow & 73 & 38 & 35 & $1.5-6$ \\
\hline Camel & 37 & 17 & 20 & $3-7$ \\
\hline Sheep and goat & 62 & 35 & 27 & $1-4$ \\
\hline Total & 246 & 134 & 112 & $<1-7$ \\
\hline
\end{tabular}

One gram portion of tissue samples was digested by wet ashing as described by Valentine et al (1987) using a mixture of nitric and perchloric acids $(1: 1 \mathrm{v} / \mathrm{v})$ on hot plate until digestion of the organic matter and evaporation to dryness, then $15 \mathrm{ml}$ of $6 \mathrm{~N} \mathrm{HCl}$ were added. Meanwhile, serum samples were diluted with n-butanes and bi-distilled water $(6: 94 \mathrm{v} / \mathrm{v})$. The prepared samples were analyzed for selenium concentration using atomic absorption spectrophotometer, Thermo MQZ-environment (graphite + hydride) with detection limit as low as $0.05 \mathrm{ppb}$.

Results were statistically analyzed according to Selvin (1996).

\section{RESULTS}

Seleinum level in serum and tissues of slaughtered animals in Ismailia governorate is presented in Tables 2 and 3 
Assiut Vet. Med. J. Vol. 54 No. 117 April 2008 
Table 3: Status of Selenium in Slaughtered Animals in Relation to Selenium Concentration in Serum and Liver*

\begin{tabular}{|l|c|c|c|c|}
\hline \multirow{2}{*}{ Animal } & \multicolumn{2}{c|}{ Serum } & \multicolumn{2}{c|}{ Liver } \\
\cline { 2 - 5 } & Low & Adequate & Low & Adequate \\
\hline Buffalo & $95.9 \%$ & $4.1 \%$ & $66.7 \%$ & $33.3 \%$ \\
\hline Cow & $82.9 \%$ & $17.1 \%$ & $100.0 \%$ & $0.0 \%$ \\
\hline Camel & $100.0 \%$ & $0.0 \%$ & $0.0 \%$ & $100.0 \%$ \\
\hline Sheep \& Goat & $90.9 \%$ & $9.1 \%$ & $100.0 \%$ & $0.0 \%$ \\
\hline
\end{tabular}

* According to Puls (1994) for cattle and Jeffery and Hall (2005) for camel

\section{DISCUSSION}

The obtained results in this study revealed that selenium level in the serum doesn't significantly differ $(\mathrm{P}>0.05)$ between sexes in the same animal except for sheep and goat, where females' sera were significantly higher in selenium level than males $(\mathrm{P}<0.05)$ as shown in Table (2). Generally selenium level in the animals' sera considered to be low according to the level stated by Puls (1994), where 82.9 to $100 \%$ of the examined sera of animals slaughtered in Ismailia slaughterhouse were below the level (Table 3) this result agreed with Perry et al. (1978) for cows and Hermülheim et al., (1992) for sheep and goats.

The selenium level in the serum reflects the nutritional status of the animals, the result which indicates the low selenium sources in animals' ration. A low level of dietary selenium eventually lowered $(\mathrm{P}<.05)$ level of blood serum selenium, but more than 8 weeks were necessary to cause a significant decline. However, when depleted calves were fed a diet containing $0.2 \mathrm{mg}$ selenium $/ \mathrm{kg}$, serum selenium levels increased $(\mathrm{P}<0.05)$ in 1 to 2 weeks (Perry et al., 1976). In the same direction, Hermülheim et al. (1992) demonstrated that this level can be increased remarkably over 24 hours after adding of selenium to the ration.

Unlike the serum, levels of selenium in tissues don't reflect the selenium level in the ration, but the reservoir of the selenium in the animal. Results in table 2 reveal the level of selenium in kidney, liver and muscles. It was obvious that level of selenium in tissues of female were significantly $(\mathrm{P}<0.05)$ higher than male in buffalo, sheep and goat, but not in cow $(\mathrm{P}>0.05)$.

Concerning the level of selenium in liver in the present investigation when compared with the levels stated by Puls (1994) (0.17 ppm) all cows, sheep and goats and $66.7 \%$ of buffaloes were concerned 
as low level (Table 3), the result which agrees with Perry, et al. (1978) who recorded a level of $0.116 \mathrm{ppm}$ in cow's liver. On the contrary $100 \%$ of camels contained adequate level of selenium in their liver (Table 3), which may be attributed to the relatively large age of camels at the time of slaughtering.

In spite of the generally low level of selenium in both serum and tissues of slaughtered animals in Ismailia slaughterhouse as recorded in this study, no distinct symptoms of nutritional myopathy were observed in the slaughtered animals. These results came in consistency with López Alonso et al. (1998) who suggested that the low selenium level found in the ewes did not cause alterations in their development.

In conclusion we can state that most of the animals slaughtered in Ismailia governorate are deficient in selenium and need to be supplemented with selenium in their ration, although these animals can tolerate a low level of selenium without altering their growth.

\section{ACKNOWLEDGEMENT}

This study in sponsored through the Egyptian Finnish Agriculture Research Project (EFARP). The authors are greatly indebted to Prof. Dr. Hosni El-Sawah, Prof. Dr. Salwa Dogheim, Prof. Dr. Hoda Abdel Ghani and Prof. Dr. Ahmed Samy for their help and encouragement to fulfill this work.

\section{REFERENCES}

Alexander, J. (2007): Selenium. Dietary Supplements and Health Novartis. Bock, G. and Goode, J. (eds). Novartis Found Symp.; 282:143149 ;

Barclay, M.N.I.; Allan, M. and James, D. (1995): "Selenium content of a range of UK food". J. Food Composition and Analysis 8: 307318.

Davis, P.A.; McDowell, L.R.; Wilkinson, N.S.; Buergelt, C.D.; Van Alstyne, R.; Weldon, R.N. and Marshall, T.T. (2006): Tolerance of inorganic selenium by range-type ewes during gestation and lactation. J. Anim. Sci. 84(3): 660-668.

Hermülheim, A.; Schramel, P.; Bostedt, H. and Wosnik, M. (1992): The selenium content in the blood of newborn sheep and goats-equally contributing to the effect of supplemental oral selenium as a prophylaxis. Tierarztl Prax. 20(3):259-263. 
Jeffery, O. and Hall, D.V.M. (2005): Selenium Deficiency in Camels. http://www.camelphotos.com/selenium.html

Kay, R.G. and Knight, G.S. (1979): Blood selenium values in an adult Auckland population group. N Z Med. J. 90(639):11-13.

Kozat, S. (2007): Serum T3 and T4 concentrations in lambs with nutritional myodegeneration. J. Vet. Intern. Med. 21(5):11351137.

López Alonso, M.; Castillo, C.; Miranda, M.; Hernández, J.; Ayala, I. and Benedito, J.L. (1998): The influence of reproductive stage on the selenium status of sheep in a low-selenium region. Acta. Vet. Hung.; 46 (1): 101-9.

Perry, T.W.; Peterson, R.C.; Griffin, D.D. and Beeson, W.M. (1978): Relationship of blood serum selenium levels of pregnant cows to low dietary intake, and effect on tissue selenium levels of their calves. J. Anim. Sci. 46: 562-565.

Perry, T.W.; Beeson, W.M.; Smith, W.H. and Mohler, M.T. (1976): Effect of supplemental selenium on performance and deposit of selenium in blood and hair of finishing cattle. J. Anita. Sci. 42:192.

Puls, R. (1994): Mineral levels in animal health: diagnostic data. $2^{\text {nd }}$ BC. Sherpa international, Canada.

Qin, S.; Gao, J. and Huang, K. (2007): Effects of different selenium sources on tissue selenium concentrations, blood GSH-Px activities and plasma interleukin levels in finishing lambs. Biol. Trace. Elem. Res. 116(1): 91-102.

Sánchez, J.; Jiménez, A.; Regodón, S. and Andrés, S. (2008): Inhibitory Effect of selenium supplementation on the reproductive performance in synchronized merino sheep at range conditions in a selenium-deficient area. Reprod Domest Anim. 22 [Epub ahead of print]

Schering Health (1988): Selenium and copper deficiencies in cattle. Veterinary Med. Pub. Co. Kansas Inc.

Selvin, W. (1996): Statistical Analysis of Epidemiologic Data. $2^{\text {nd }}$ ed. Oxford University Press, New York.

Smith, M.L.; Lancia, J.K.; Mercer, T.I. and Ip, C. (2004): Selenium compounds regulate p53 by common and distinctive mechanisms. Anticancer Res. 24(3a): 1401-1408.

Swecker, W.S. (1990): Selenium supplementation and selected immune responses of beef cattle. Ph.D. dissertation. Dept. of Vet. Med. Virginia polytechnic institute, Blacksburg. 
Tiwary, A.K.; Stegelmeier, B.L.; Panter, K.E.; James, L.F. and Hall, J.O. (2006): Comparative toxicosis of sodium selenite and selenomethionine in lambs. J. Vet. Diagn. Invest. 18(1):61-70.

Valentine, J.L.; Reisbord, L.S.; Kang, H.K. and Schluchter, M.D. (1987): Effects on human health of exposure to Se in drinking water. Pp. 675-687. Selenium in Biology and Medicine: Proceedings of the Third International Symposium on Selenium in Biology and Medicine, May 27-June 1, New York. 
Table 2: Selenium Level (ppb) in Serum and Tissues of Slaughtered Animals at Ismailia Slaughterhouse

\begin{tabular}{|c|c|c|c|c|c|c|c|c|c|c|c|}
\hline \multirow{2}{*}{$\bigcup_{\text {Sex }}^{\text {Tissue }}$} & \multicolumn{3}{|c|}{ Serum } & \multicolumn{3}{|c|}{ Kidney } & \multicolumn{3}{|c|}{ Liver } & \multicolumn{2}{|r|}{ Muscle } \\
\hline & Min & Max & Average & Min & Max & Average & Min & Max & Average & Min & Max \\
\hline Total & $<0.05$ & 7.21 & 2.37 & 35.54 & 520.50 & 213.92 & 15.71 & 633.37 & 214.82 & 107.44 & 292.12 \\
\hline Female & 0.93 & 5.51 & 2.71 & 35.54 & 520.50 & $260.40 \mathrm{a}$ & 95.42 & 633.37 & $364.40 \mathrm{a}$ & 107.44 & 292.12 \\
\hline Male & $<0.05$ & 7.21 & 2.28 & 56.74 & 250.13 & $140.05 \mathrm{~b}$ & 15.71 & 366.16 & $140.03 \mathrm{~b}$ & 124.31 & 227.81 \\
\hline Total & $<0.05$ & 19.13 & 4.21 & 42.6 & 280.14 & 125.9 & 37.78 & 320.2 & 125.68 & 29.34 & 265.9 \\
\hline Female & 2.33 & 17.40 & 6.74 & 42.6 & 265.3 & 105.36 & 37.78 & 280.36 & 120.58 & 29.34 & 48.32 \\
\hline Male & $<0.05$ & 19.13 & 3.94 & 45.35 & 280.14 & 145.63 & 47.36 & 320.2 & 160.25 & 36.58 & 265.9 \\
\hline Total & $<0.05$ & 20.34 & 12.15 & 195.8 & 395.02 & 295.41 & 230.30 & 444.34 & 337.32 & 201.43 & 420.01 \\
\hline Female & - & - & - & - & - & - & & - & - & - & - \\
\hline Male & $<0.05$ & 20.34 & 12.15 & 195.8 & 395.02 & 295.41 & 230.30 & 444.34 & 337.32 & 201.43 & 420.01 \\
\hline Total & $<0.05$ & 42.16 & 9.36 & 56.52 & 270.35 & 140.65 & 65.30 & 784.55 & 465.20 & $<0.05$ & 220.30 \\
\hline Female & $<0.05$ & 42.16 & $21.08 \mathrm{a}$ & 68.23 & 270.35 & $168.50 \mathrm{a}$ & 95.60 & 784.55 & $490.60 \mathrm{a}$ & $<0.05$ & 220.30 \\
\hline Male & 0.25 & 3.55 & $1.55 \mathrm{~b}$ & 56.52 & 170.35 & $132.00 \mathrm{~b}$ & 65.30 & 366.20 & $252.80 \mathrm{~b}$ & 12.03 & 160.12 \\
\hline
\end{tabular}

There are significance difference $(\mathrm{P}<0.05)$ between cells having different letters in the same column 